\title{
Impact of pre-existing cardiovascular disease on treatment patterns and survival outcomes in patients with lung cancer
}

\author{
Atul Batra ${ }^{1,2}$, Dropen Sheka ${ }^{2}$, Shiying Kong ${ }^{2}$ and Winson Y. Cheung ${ }^{1,2^{*}}$
}

\begin{abstract}
Background: Baseline cardiovascular disease (CVD) can impact the patterns of treatment and hence the outcomes of patients with lung cancer. This study aimed to characterize treatment trends and survival outcomes of patients with pre-existing CVD prior to their diagnosis of lung cancer.

Methods: We conducted a retrospective, population-based cohort study of patients with lung cancer diagnosed from 2004 to 2015 in a large Canadian province. Multivariable logistic regression and Cox regression models were constructed to determine the associations between CVD and treatment patterns, and its impact on overall (OS) and cancer-specific survival (CSS), respectively. A competing risk multistate model was developed to determine the excess mortality risk of patients with pre-existing CVD.

Results: A total of 20,689 patients with lung cancer were eligible for the current analysis. Men comprised 55\%, and the median age at diagnosis was 70 years. One-third had at least one CVD, with the most common being congestive heart failure in 15\% of patients. Pre-existing CVD was associated with a lower likelihood of receiving chemotherapy (odds ratio [OR], 0.53; 95\% confidence interval [Cl], 0.48-0.58; $P<.0001)$, radiotherapy $(\mathrm{OR}, 0.76 ; 95 \%$ $\mathrm{Cl}, 0.7-0.82 ; P<.0001)$, and surgery $(\mathrm{OR}, 0.56 ; 95 \% \mathrm{Cl}, 0.44-0.7 ; P<.0001)$. Adjusting for measured confounders, the presence of pre-existing CVD predicted for inferior OS (hazard ratio $[\mathrm{HR}], 1.1 ; 95 \% \mathrm{Cl}, 1.1-1.2 ; P<.0001)$ and CSS (HR, $1.1 ; 95 \% \mathrm{Cl}, 1.1-1.1 ; P<.0001)$. However, in the competing risk multistate model that adjusted for baseline characteristics, prior CVD was associated with increased risk of non-cancer related death $(\mathrm{HR}, 1.48 ; 95 \% \mathrm{Cl}, 1.33-1.64$; $P<0.0001)$ but not cancer related death $(\mathrm{HR}, 0.98 ; 95 \% \mathrm{Cl}, 0.94-1.03 ; P=0.460)$.
\end{abstract}

Conclusions: Patients with lung cancer and pre-existing CVD are less likely to receive any modality of cancer treatment and are at a higher risk of non-cancer related deaths. As effective therapies such as immuno-oncology drugs are introduced, early cardio-oncology consultation may optimize management of lung cancer.

Keywords: Lung cancer, Cardiovascular disease, Cardio-oncology, Treatment trends, Survival outcomes

\section{Background}

Cardiovascular disease and cancer are the two leading causes of death worldwide, and account for approximately 17.9 million and 9.6 million deaths annually

\footnotetext{
* Correspondence: winson.cheung@ahs.ca

${ }^{1}$ Department of Medical Oncology, Tom Baker Cancer Center, 133129 ST NW, Calgary, Alberta T2N 4N2, Canada

${ }^{2}$ University of Calgary, Calgary, Alberta, Canada
}

across the globe, respectively [1-3]. The relationship between these two comorbid conditions is complex. While cardiovascular disease and cancer share common modifiable risk factors and pathophysiological mechanisms, the treatments and outcomes of one may be affected by the other [4-9]. Further, cancer treatments, including chemotherapy, targeted therapy, and radiotherapy, have

C C The Author(s). 2020 Open Access This article is licensed under a Creative Commons Attribution 4.0 International License, which permits use, sharing, adaptation, distribution and reproduction in any medium or format, as long as you give appropriate credit to the original author(s) and the source, provide a link to the Creative Commons licence, and indicate if changes were made. The images or other third party material in this article are included in the article's Creative Commons licence, unless indicated otherwise in a credit line to the material. If material is not included in the article's Creative Commons licence and your intended use is not permitted by statutory regulation or exceeds the permitted use, you will need to obtain permission directly from the copyright holder. To view a copy of this licence, visit http://creativecommons.org/licenses/by/4.0/ The Creative Commons Public Domain Dedication waiver (http://creativecommons.org/publicdomain/zero/1.0/) applies to the data made available in this article, unless otherwise stated in a credit line to the data. 
been associated with increased downstream cardiovascular sequelae, independent of other risk factors [10].

For example, cigarette smoking is estimated to contribute to $71 \%$ of lung cancer related mortality and $10 \%$ of deaths due to cardiovascular disease, respectively [11]. Inflammation and oxidative stress are key mechanisms in the pathophysiology of both conditions [12-14]. The other link between lung cancer and cardiovascular disease is advanced age. The median age at the diagnosis of cardiovascular disease is 65 years and that for lung cancer is 70 years $[15,16]$.

Previous studies have primarily focused on the longterm cardiovascular complications of cancer treatments $[17,18]$. Data related to the prevalence of pre-existing cardiovascular diseases in patients diagnosed with cancer has been reported to range from 5 to $43 \%$, depending on the primary site of malignancy and the geographical region where the study was conducted [19, 20]. However, there are limited studies reporting on the impact of preexisting cardiovascular disease on subsequent treatment patterns and survival outcomes of lung cancer. A large study of patients with breast cancer concluded that those with baseline cardiovascular disease were less likely to receive any form of therapy (surgery, chemotherapy, hormonal therapy, and radiotherapy) compared to patients without pre-existing cardiovascular comorbidities [21]. Further, overall survival but not cancer specific survival was shorter in these patients. While a few studies have described inferior survival outcomes among patients with lung cancer and pre-existing cardiovascular disease, the effect of treatments on prognosis remains largely unknown $[22,23]$.

In this study, we aimed to identify the proportion of patients who had at least one pre-existing cardiovascular disease at the time of their diagnosis of lung cancer. Further, we analyzed the effect of pre-existing cardiovascular disease on treatment patterns, including chemotherapy, radiation therapy, and surgery, as well as its impact on survival outcomes in patients with lung cancer.

\section{Methods}

\section{Data sources and study population}

The study was conducted in Alberta, which is a large province in Canada, with a population of over 4 million people and has a single-payer, universal healthcare system. This was a retrospective, population-based study, where we compiled data from various administrative sources including the Alberta cancer registry (ACR), hospital discharge abstracts, national ambulatory care reporting system, provincial physician billing claims, vital statistics, and the 2011 census.
The ACR prospectively records data on all residents diagnosed with cancer in the province, including demographic variables, tumor characteristics, and primary treatment patterns. The discharge abstracts provide data collected during hospital admissions and details up to 25 International Classification of Diseases tenth version (ICD-10) diagnoses and up to 20 procedures coded as per the Canadian Classification of Health Interventions. Likewise, the ambulatory care data record up to 10 diagnoses and 10 procedures, respectively. The provincial physician billing claims data provide the location of healthcare delivery, physician specialty, one procedure code, and up to three ICD-10 diagnoses. Each patient in the province has a unique provincial health number, which was used to link the data from the various sources. Data on death from lung cancer or other causes were retrieved from vital statistics.

Patients aged 18 years and older with a diagnosis of lung cancer between January 1, 2004, and December 31, 2015, in Alberta, Canada were included in the current analysis. Patients who moved out of Alberta within 12 months of primary treatment, those who had multiple primary tumors, or who did not have an Alberta healthcare number were excluded.

Approval was obtained from the Health Research Ethics Board of Alberta's Cancer Committee prior to commencing this study.

\section{Clinical variables and outcomes Outcomes}

The main outcomes of this study were treatment patterns and survival outcomes. We assessed the impact of pre-existing cardiovascular disease on treatments, including the receipt of any chemotherapy, surgery, and radiotherapy. Primary surgery type was identified as the most definitive surgical procedure (lobectomy or segmental resection or pneumonectomy) performed within 1 year of diagnosis. Information on the administration of chemotherapy and radiotherapy was categorized in a binary fashion (yes or no), which was obtained via the ACR. Survival outcomes including overall survival (OS) and cancer specific survival (CSS) were retrieved from vital statistics records.

\section{Independent variables}

Using data from the above sources, the presence of pre-existing cardiovascular disease at or preceding the time of diagnosis of lung cancer was identified using previously validated ICD algorithms [24]. Cardiovascular diseases included the presence of congestive heart failure, myocardial infarction, cerebrovascular accident and/or arrhythmias. Tumor characteristics 
included the American Joint Committee on Cancer stage and histologic type or subtype (adenocarcinoma, squamous cell carcinoma, small cell lung cancer, carcinoid, large cell cancer, and others). The discharge abstracts, physician billing claims, and ambulatory care data were used to derive the Charlson comorbidity index. Alberta is strategically divided into five health zones for healthcare delivery. Postal code at diagnosis was used to assign each patient to their respective health zone (Calgary, Edmonton, North, Central, or South) and to retrieve neighbourhood-level socioeconomic status (education and income levels) based on the 2011 census. Driving time to the nearest oncology facility was calculated using Google Maps interface and postal codes, and it was further categorized as one, one to two and more than $2 \mathrm{~h}$, as per previously published literature [25].

\section{Statistical analysis}

Baseline characteristics were summarized using descriptive statistics, where the Student's t test and Wilcoxon rank-sum test were used to compare continuous variables, and the chi-square tests were applied to compare categorical variables across the different patient groups. Multivariable logistic regression analyses were performed to identify associations between pre-existing cardiovascular disease and receipt of treatment (including chemotherapy, radiotherapy, and surgery). We also performed age and histology stratified logistic regression analyses for each treatment modality. Kaplan-Meier curves were plotted to estimate OS and CSS differences between patients with and without cardiovascular disease, and compared using log rank tests. Cox proportional hazards models were constructed to examine the effect of pre-existing cardiovascular disease on OS and CSS, respectively. The proportional hazard assumptions for the regression models were tested using Schoenfeld residuals. These models were further stratified by age and histology. OS and CSS were defined as the time interval between the date of cancer diagnosis and the date of death from any cause, and the date of death from lung cancer, respectively. Further, we also constructed a competing risk multistate model with three states: alive, cancer related death and non-cancer related death, to examine the excess mortality risk of patients with preexisting cardiovascular disease. Subgroup analyses were performed to investigate whether the effects of cardiovascular disease on outcomes were modified by different treatments, including chemotherapy, surgery, and radiotherapy. All tests were two-sided, and the significance level was defined a priori as 0.05 . All analyses were performed with SAS statistical software version 9.4 (SAS Institute, Inc., Cary, NC).

\section{Results}

\section{Patient characteristics}

A total of 20,689 patients were diagnosed with lung cancer during the study period. The median age at diagnosis was 70 (interquartile range, 62-78) years, and women constituted $49 \%$ of the cohort. Approximately half of patients had distant metastases at diagnosis. Adenocarcinoma (37.3\%) and squamous cell carcinoma (17.8\%) were the most common histologies, while small cell lung cancer was diagnosed in $12.4 \%$. Surgery was performed in $16.5 \%$, and chemotherapy and radiation therapy were administered in 27.4 and $30.3 \%$ of patients, respectively. Only 20 patients $(0.1 \%)$ received immunotherapy. Additional baseline characteristics are shown in Table 1.

\section{Pre-existing cardiovascular diseases}

Of all patients with lung cancer, 6436 (31.1\%) had at least one pre-existing cardiovascular disease. The most common pre-existing cardiovascular disease at the diagnosis of lung cancer included congestive heart failure (47.4\%), followed by previous cerebrovascular accident (40.3\%), myocardial infarction (33.0\%), and chronic arrythmias (30.4\%), respectively (Table 2).

Patients with pre-existing cardiovascular disease were more likely to be older (mean age 73.7 vs. 67.6 years, $P<$ $0.0001)$, male ( $55.3 \%$ vs. $48.9 \%, P<0.0001)$, have a higher burden of comorbid conditions (Charlson comorbidity index score $>1,85.4 \%$ vs. $70.2 \%, P<0.0001$ ), and advanced stages of lung cancer at diagnosis (stage III and IV, $74.5 \%$ vs. $75.6 \%, P<0.0001)$. Similarly, they were more likely to have lower neighborhood-level income $(<$ $46 \mathrm{~K}$ per year, $36.4 \%$ vs. $38.4 \%, P=0.0237$ ) and education levels (> 80\% population attained high-school or greater, $48.9 \%$ vs. $51.8 \%, P=0.0005$ ), and also tended to reside rurally $(37.5 \%$ vs. $34.6 \%, P<0.0001)$. The driving time from place of residence to cancer center ( $>2 \mathrm{~h}, 11.2 \%$ vs $11.7 \%, P<0.0001)$ was also longer in this subpopulation.

Patients with lung cancer and pre-existing cardiovascular disease were less likely to be treated with surgery $(11.2 \%$ vs. $18.9 \%, P<0.0001)$, chemotherapy $(16.4 \%$ vs. $32.3 \%, P<0.0001)$, or radiotherapy $(26.3 \%$ vs. $32.1 \%, P<$ 0.0001). Moreover, such patients were more likely to be treated in community centers rather than academic institutions $(51.5 \%$ vs. $46.7 \%, P<0.0001)$.

\section{Pre-existing cardiovascular disease and treatment patterns}

We used multivariable logistic regression analysis to assess the impact of pre-existing cardiovascular disease on lung cancer treatment, including chemotherapy, radiation therapy, and surgery (Table 3). Adjusting for baseline variables including age, sex, year of diagnosis, Charlson comorbidity index, histological subtype, stage ( $\mathrm{T}, \mathrm{N}$, and $\mathrm{M}$ ), laterality, other treatments, management 
Table 1 Baseline characteristics of patients with lung cancer

\begin{tabular}{|c|c|c|c|c|}
\hline Variables & $\begin{array}{l}\text { Total }(N=20, \\
689) \\
\mathrm{n}(\%)\end{array}$ & $\begin{array}{l}\text { With cardiovascular disease }(N= \\
6436), \\
\mathrm{n}(\%)\end{array}$ & $\begin{array}{l}\text { Without cardiovascular disease }(N=14, \\
253) \\
\text { n (\%) }\end{array}$ & $P$-value \\
\hline Age, in years & & & & $<0.0001$ \\
\hline Mean (+STD) & $69.5( \pm 11)$ & $73.7( \pm 9.7)$ & $67.6( \pm 11.1)$ & \\
\hline Median (IQR) & $70(62-78)$ & $75(67-81)$ & $68(60-76)$ & \\
\hline Age group & & & & $<0.0001$ \\
\hline$<=60$ & $4443(21.5 \%)$ & $658(10.2 \%)$ & 3785 (26.6\%) & \\
\hline $61-70$ & 6112 (29.5\%) & $1549(24.1 \%)$ & 4563 (32\%) & \\
\hline $71-80$ & 6717 (32.5\%) & $2590(40.2 \%)$ & 4127 (29\%) & \\
\hline$>80$ & 3417 (16.5\%) & $1639(25.5 \%)$ & $1778(12.5 \%)$ & \\
\hline Sex & & & & $<0.0001$ \\
\hline Female & 10,156 (49.1\%) & $2874(44.7 \%)$ & $7282(51.1 \%)$ & \\
\hline Male & $10,533(50.9 \%)$ & $3562(55.3 \%)$ & 6971 (48.9\%) & \\
\hline Year of diagnosis & & & & 0.0337 \\
\hline 2004-2009 & 9993 (48.3\%) & $3038(47.2 \%)$ & $6955(48.8 \%)$ & \\
\hline 2010-2015 & $10,696(51.7 \%)$ & 3398 (52.8\%) & 7298 (51.2\%) & \\
\hline $\mathrm{CCl}$ score & & & & $<0.0001$ \\
\hline 0 & 2566 (12.4\%) & $310(4.8 \%)$ & $2256(15.8 \%)$ & \\
\hline 1 & 2614 (12.6\%) & 627 (9.7\%) & $1987(13.9 \%)$ & \\
\hline$>1$ & $15,509(75 \%)$ & $5499(85.4 \%)$ & $10,010(70.2 \%)$ & \\
\hline Histology & & & & $<0.0001$ \\
\hline Adenocarcinoma & 7727 (37.3\%) & $2024(31.4 \%)$ & $5703(40 \%)$ & \\
\hline SCC & $3680(17.8 \%)$ & $1184(18.4 \%)$ & 2496 (17.5\%) & \\
\hline $\mathrm{SCLC}$ & $2571(12.4 \%)$ & 799 (12.4\%) & 1772 (12.4\%) & \\
\hline Carcinoid/LCNE & $520(2.5 \%)$ & $117(1.8 \%)$ & $403(2.8 \%)$ & \\
\hline Large cell cancer & $260(1.3 \%)$ & $59(0.9 \%)$ & 201 (1.4\%) & \\
\hline Others & $5931(28.7 \%)$ & $2253(35 \%)$ & 3678 (25.8\%) & \\
\hline \multicolumn{5}{|l|}{ Stage } \\
\hline 1 & 3636 (17.6\%) & $1127(17.5 \%)$ & 2509 (17.6\%) & $<0.0001$ \\
\hline$\|$ & $880(4.3 \%)$ & 250 (3.9\%) & 630 (4.4\%) & \\
\hline III & $5168(25 \%)$ & 1591 (24.7\%) & 3577 (25.1\%) & \\
\hline IV & 10,409 (50.3\%) & 3207 (49.8\%) & 7202 (50.5\%) & \\
\hline Unknown & 596 (2.9\%) & $261(4.1 \%)$ & 335 (2.4\%) & \\
\hline \multicolumn{5}{|l|}{ T stage } \\
\hline T0 & $110(0.5 \%)$ & $44(0.7 \%)$ & $66(0.5 \%)$ & $<0.0001$ \\
\hline T1 & 3095 (15\%) & 985 (15.3\%) & 2110 (14.8\%) & \\
\hline $\mathrm{T} 2$ & 6581 (31.8\%) & 2001 (31.1\%) & 4580 (32.1\%) & \\
\hline T3 & 788 (3.8\%) & 188 (2.9\%) & $600(4.2 \%)$ & \\
\hline T4 & 9378 (45.3\%) & 2966 (46.1\%) & $6412(45 \%)$ & \\
\hline Unknown & 737 (3.6\%) & 252 (3.9\%) & 485 (3.4\%) & \\
\hline \multicolumn{5}{|l|}{$\mathrm{N}$ stage } \\
\hline NO & 6540 (31.6\%) & 2126 (33\%) & 4414 (31\%) & $<0.0001$ \\
\hline N1 & $1729(8.4 \%)$ & 494 (7.7\%) & 1235 (8.7\%) & \\
\hline N2 & 7453 (36\%) & $2302(35.8 \%)$ & 5151 (36.1\%) & \\
\hline N3 & 3803 (18.4\%) & $1073(16.7 \%)$ & $2730(19.2 \%)$ & \\
\hline
\end{tabular}


Table 1 Baseline characteristics of patients with lung cancer (Continued)

\begin{tabular}{|c|c|c|c|c|}
\hline Variables & $\begin{array}{l}\text { Total }(N=20, \\
689) \\
\mathrm{n}(\%)\end{array}$ & $\begin{array}{l}\text { With cardiovascular disease }(N= \\
6436), \\
\text { n (\%) }\end{array}$ & $\begin{array}{l}\text { Without cardiovascular disease }(N=14, \\
253) \\
\text { n (\%) }\end{array}$ & $P$-value \\
\hline Unknown & $1164(5.6 \%)$ & 441 (6.9\%) & $723(5.1 \%)$ & \\
\hline \multicolumn{5}{|l|}{ M stage } \\
\hline MO & $9877(47.7 \%)$ & 3069 (47.7\%) & $6808(47.8 \%)$ & \multirow[t]{3}{*}{0.0008} \\
\hline M1 & 10,409 (50.3\%) & 3207 (49.8\%) & $7202(50.5 \%)$ & \\
\hline Unknown & 403 (1.9\%) & $160(2.5 \%)$ & $243(1.7 \%)$ & \\
\hline \multicolumn{5}{|l|}{ Laterality } \\
\hline Bilateral & $211(1 \%)$ & $74(1.1 \%)$ & 137 (1\%) & \multirow[t]{4}{*}{0.0003} \\
\hline Left & 8477 (41\%) & $2677(41.6 \%)$ & $5800(40.7 \%)$ & \\
\hline Right & 11,568 (55.9\%) & $3515(54.6 \%)$ & $8053(56.5 \%)$ & \\
\hline Unknown & $433(2.1 \%)$ & $170(2.6 \%)$ & $263(1.8 \%)$ & \\
\hline \multicolumn{5}{|l|}{ Surgery } \\
\hline No & $17,274(83.5 \%)$ & $5721(88.9 \%)$ & 11,553 (81.1\%) & \multirow[t]{3}{*}{$<0.0001$} \\
\hline $\begin{array}{l}\text { Lobectomy or } \\
\text { segmental }\end{array}$ & 3168 (15.3\%) & $686(10.7 \%)$ & $2482(17.4 \%)$ & \\
\hline Pneumonectomy & $247(1.2 \%)$ & $29(0.5 \%)$ & $218(1.5 \%)$ & \\
\hline \multicolumn{5}{|l|}{ Chemotherapy } \\
\hline No & $15,029(72.6 \%)$ & 5378 (83.6\%) & $9651(67.7 \%)$ & \multirow[t]{2}{*}{$<0.0001$} \\
\hline Yes & $5660(27.4 \%)$ & $1058(16.4 \%)$ & $4602(32.3 \%)$ & \\
\hline \multicolumn{5}{|l|}{ Immunotherapy } \\
\hline No & 20,669 (99.9\%) & $6433(100 \%)$ & 14,236 (99.9\%) & \multirow[t]{2}{*}{0.1195} \\
\hline Yes & $20(0.1 \%)$ & $3(0 \%)$ & $17(0.1 \%)$ & \\
\hline \multicolumn{5}{|l|}{ Radiation } \\
\hline No & 14,418 (69.7\%) & $4743(73.7 \%)$ & $9675(67.9 \%)$ & \multirow[t]{2}{*}{$<0.0001$} \\
\hline Yes & $6271(30.3 \%)$ & $1693(26.3 \%)$ & $4578(32.1 \%)$ & \\
\hline \multicolumn{5}{|l|}{ Institution type } \\
\hline Academic & 10,713 (51.8\%) & $3119(48.5 \%)$ & $7594(53.3 \%)$ & \multirow[t]{2}{*}{$<0.0001$} \\
\hline Community & $9976(48.2 \%)$ & 3317 (51.5\%) & $6659(46.7 \%)$ & \\
\hline \multicolumn{5}{|l|}{ Driving time (hours) } \\
\hline 1 & 15,419 (74.5\%) & 4704 (73.1\%) & 10,715 (75.2\%) & \multirow[t]{3}{*}{$<0.0001$} \\
\hline 2 & $2885(13.9 \%)$ & $1010(15.7 \%)$ & 1875 (13.2\%) & \\
\hline$>2$ & 2385 (11.5\%) & $722(11.2 \%)$ & $1663(11.7 \%)$ & \\
\hline \multicolumn{5}{|l|}{ Health Zone } \\
\hline Calgary & $6192(29.9 \%)$ & $1781(27.7 \%)$ & 4411 (30.9\%) & \multirow[t]{5}{*}{$<0.0001$} \\
\hline Central & $3125(15.1 \%)$ & $1045(16.2 \%)$ & $2080(14.6 \%)$ & \\
\hline Edmonton & 7159 (34.6\%) & $2239(34.8 \%)$ & $4920(34.5 \%)$ & \\
\hline North & $2459(11.9 \%)$ & 755 (11.7\%) & $1704(12 \%)$ & \\
\hline South & $1754(8.5 \%)$ & $616(9.6 \%)$ & $1138(8 \%)$ & \\
\hline \multicolumn{5}{|l|}{ Educational level $^{a}$} \\
\hline$<=80 \%$ & 10,133 (49\%) & 3281 (51\%) & $6852(48.1 \%)$ & \multirow[t]{3}{*}{0.0005} \\
\hline$>80 \%$ & 10,527 (50.9\%) & 3147 (48.9\%) & $7380(51.8 \%)$ & \\
\hline Unknown & $29(0.1 \%)$ & $8(0.1 \%)$ & $21(0.1 \%)$ & \\
\hline \multicolumn{5}{|l|}{ Income level } \\
\hline$<=46 \mathrm{k}$ & 12,849 (62.1\%) & 4085 (63.5\%) & $8764(61.5 \%)$ & 0.0237 \\
\hline
\end{tabular}


Table 1 Baseline characteristics of patients with lung cancer (Continued)

\begin{tabular}{|c|c|c|c|}
\hline Variables & $\begin{array}{l}\text { Total }(N=20, \\
689) \\
\mathrm{n}(\%)\end{array}$ & $\begin{array}{l}\text { With cardiovascular disease }(N= \\
6436) \\
\mathrm{n}(\%)\end{array}$ & $\begin{array}{l}\text { Without cardiovascular disease }(N=14 \text {, } \\
253), \\
\mathrm{n}(\%)\end{array}$ \\
\hline$>46 k$ & 7811 (37.8\%) & $2343(36.4 \%)$ & 5468 (38.4\%) \\
\hline Unknown & $29(0.1 \%)$ & $8(0.1 \%)$ & $21(0.1 \%)$ \\
\hline
\end{tabular}

STD Standard deviation, IQR Interquartile range, CCI Charlson's comorbidity index, SCC Squamous cell cancer, SCLC Small cell lung cancer, LCNE Large Cell Neuroendocrine tumor. ${ }^{a} 80 \%$ of residents have high school and above level of education in the neighborhood

at either academic or community center, zone of residence, driving distance from residence to nearest cancer center, education and income levels, the presence of pre-existing cardiovascular disease was associated with a lower likelihood of chemotherapy (odds ratio, 0.53; 95\% confidence interval $[\mathrm{CI}], 0.48$ to $0.58 ; P<0.0001)$, radiation therapy (odds ratio, 0.76 ; $95 \% \mathrm{CI} 0.7$ to $0.82, P<$ 0.0001 ) and surgery (odds ratio, $0.56 ; 95 \% \mathrm{CI}, 0.44$ to $0.70 ; P<0.0001)$, respectively.

In histology-stratified logistic regression analysis, presence of cardiovascular disease was associated with a lower likelihood of chemotherapy in adenocarcinoma $(P<$ $0.0001)$, squamous cell carcinoma $(P<0.0001)$, small cell lung cancer $(P<0.0001)$, large cell carcinoma $(P=0.0157)$ and other histologies $(P<0.0001)$. However, no association was observed for carcinoid and large cell neuroendocrine tumor $(P=0.1275)$. Similarly, a lower likelihood of radiotherapy was observed in patients with cardiovascular disease and adenocarcinoma $(P<0.0001)$, squamous cell carcinoma $(P=0.0009)$ and other histologies $(P<0.0001)$ but not for small cell lung cancer $(P=0.2127)$, carcinoids $(P=4417)$ and large cell carcinoma $(P=0.4259)$. Lastly, a lower likelihood for surgery was observed for adenocarcinoma $(P<0.0001)$, squamous cell cancer $(\mathrm{P}<0.0001)$, large cell carcinoma $(P=0.0046)$ and other histologies $(P=$ $0.0046)$, but not for small cell lung cancer $(P=0.0703)$ and carcinoids $(P=0.6222)$ (Supplemental Table 1A-C).

In age-stratified logistic regression analyses, presence of cardiovascular disease was associated with a lower likelihood of chemotherapy in patients aged $<=60$ years $(P<0.0001), 61-70$ years $(P<0.0001)$, and $71-80$ years $(P<0.0001)$ and but not in $>80$ years $(P=0.0694)$. A lower likelihood of radiotherapy and surgery was observed in patients with cardiovascular disease across all age groups (Supplemental Table 2A-C).

\section{Impact of pre-existing cardiovascular disease on survival outcomes}

The median overall survival (OS) of patients with lung cancer and pre-existing cardiovascular disease was significantly shorter (5.3 [95\% CI, 5.1-5.6] months) compared with those without any baseline cardiovascular disease (9.2[95\% CI, 8.9-9.6] months, $P<0.0001$ ) (Fig. 1). Likewise, cancer specific survival (CSS) was significantly shorter for those with pre-existing cardiovascular disease (6.0 vs 9.8 months, $P<0.0001$ ).

A multivariable Cox regression model was constructed to analyze the factors that impacted OS and CSS (Table 4). Adjusting for baseline factors, pre-existing cardiovascular disease was predictive of inferior OS (hazard ratio $[\mathrm{HR}], 1.1 ; 95 \% \mathrm{CI}, 1.1$ to $1.2 ; P<0.0001)$, as well as shorter CSS (HR, 1.1; 95\% CI, 1.1 to $1.1 ; P<$ 0.0001 ), respectively. Other factors predictive of shorter OS and CSS included older age, male sex, Charlson comorbidity index $>1$, histologies other than carcinoid and adenocarcinoma, advanced TNM stage, and $>2 \mathrm{~h}$ drive from residence to the nearest cancer center. Conversely, treatment with surgery, chemotherapy, or radiotherapy predicted longer OS and CSS. Notably, treatment setting (academic vs community treatment center), education, and income did not influence survival outcomes. The proportional hazard assumption was verified by plotting the unadjusted OS and CSS curves prior to performing the Cox proportional hazards analysis (Fig. 1a and c). Testing the Schoenfeld residuals for the Cox regression models for OS and CSS showed that the proportional hazards assumption was met.

Therefore, we performed age-stratified Cox regression analyses for age groups: $\leq 60$ years, $61-70$ years, $71-80$ years and $>80$ years. Presence of baseline cardiovascular disease predicted worse CSS ( $\leq 60$ years: HR, 1.01; $95 \%$

Table 2 Type of cardiovascular disease

\begin{tabular}{lll}
\hline Cardiovascular disease & $\begin{array}{l}\text { Number (percentage of those with cardiovascular disease) } \\
(\boldsymbol{n}=\mathbf{6 4 3 6 )}\end{array}$ & $\begin{array}{l}\text { Percentage of overall population } \\
(\boldsymbol{n}=\mathbf{2 0 , 6 8 9})\end{array}$ \\
\hline Previous myocardial infarction & $2127(33 \%)$ & $10.3 \%$ \\
Congestive heart failure & $3049(47.4 \%)$ & $14.7 \%$ \\
Cerebrovascular accident & $2596(40.3 \%)$ & $12.5 \%$ \\
Chronic arrhythmias & $1954(30.4 \%)$ & $9.4 \%$ \\
\hline
\end{tabular}


Table 3 Multivariable Logistic regression for factors associated with surgery, chemotherapy, and radiation therapy in patients with lung cancer

\begin{tabular}{|c|c|c|c|c|c|c|}
\hline \multirow[t]{2}{*}{ Variable } & \multicolumn{2}{|l|}{ Chemotherapy } & \multicolumn{2}{|l|}{ Radiation } & \multicolumn{2}{|l|}{ Surgery } \\
\hline & $\begin{array}{l}\text { Odds Ratio } \\
\text { (95\% Confidence Limit) }\end{array}$ & $P$ value & $\begin{array}{l}\text { Odds Ratio } \\
\text { (95\% Confidence Limit) }\end{array}$ & $P$ value & $\begin{array}{l}\text { Odds Ratio } \\
\text { (95\% Confidence Limit) }\end{array}$ & $P$ value \\
\hline \multicolumn{7}{|l|}{ Age group } \\
\hline$<=60$ & Reference & & Reference & & Reference & \\
\hline $61-70$ & 0.68 (0.62 to 0.75$)$ & $<0.0001$ & 0.82 (0.74 to 0.9 ) & $<0.0001$ & 0.57 (0.44 to 0.75$)$ & $<0.0001$ \\
\hline $71-80$ & 0.34 (0.30 to 0.37$)$ & $<0.0001$ & 0.61 (0.55 to 0.67 ) & $<0.0001$ & 0.35 (0.27 to 0.46$)$ & $<0.0001$ \\
\hline$>80$ & 0.09 (0.08 to 0.11$)$ & $<0.0001$ & 0.38 (0.34 to 0.43$)$ & $<0.0001$ & 0.12 (0.08 to 0.18 ) & $<0.0001$ \\
\hline \multicolumn{7}{|l|}{ Sex } \\
\hline Female & Reference & & Reference & & Reference & \\
\hline Male & 0.92 (0.85 to 0.99$)$ & 0.0225 & 1.11 (1.04 to 1.18$)$ & 0.0029 & 0.99 (0.82 to 1.21$)$ & 0.9448 \\
\hline Year of diagnosis & 1.01 (1 to 1.02 ) & 0.0337 & 1.00 (0.99 to 1.01 ) & 0.6327 & 0.99 (0.96 to 1.02 ) & 0.4833 \\
\hline \multicolumn{7}{|l|}{ CCl score } \\
\hline 0 & Reference & & Reference & & Reference & \\
\hline 1 & 0.77 (0.67 to 0.89$)$ & 0.0002 & 1.02 (0.89 to 1.17 ) & 0.7471 & 0.79 (0.55 to 1.13$)$ & 0.1945 \\
\hline$>1$ & 0.68 (0.61 to 0.75$)$ & $<0.0001$ & 1.16 (1.04 to 1.29$)$ & 0.0058 & 0.68 (0.52 to 0.9$)$ & 0.0078 \\
\hline \multicolumn{7}{|c|}{ Cardiovascular disease } \\
\hline No & Reference & & Reference & & Reference & \\
\hline Yes & 0.53 (0.48 to 0.58$)$ & $<0.0001$ & 0.76 (0.70 to 0.82 ) & $<0.0001$ & 0.56 (0.44 to 0.7$)$ & $<0.0001$ \\
\hline \multicolumn{7}{|l|}{ Histology } \\
\hline Adenocarcinoma & Reference & & Reference & & Reference & \\
\hline SCC & 0.61 (0.55 to 0.68$)$ & $<0.0001$ & 0.77 (0.71 to 0.85 ) & $<0.0001$ & 0.12 (0.08 to 0.16 ) & $<0.0001$ \\
\hline SCLC & 6.64 (5.93 to 7.45$)$ & $<0.0001$ & 2.17 (1.96 to 2.39 ) & $<0.0001$ & 0.47 (0.37 to 0.61 ) & $<0.0001$ \\
\hline Carcinoid/LCNE & 1.05 (0.84 to 1.31$)$ & 0.6779 & 0.82 (0.62 to 1.08 ) & 0.1480 & 3.46 (2.16 to 5.54$)$ & $<0.0001$ \\
\hline Large cell ca & 0.79 (0.58 to 1.08$)$ & 0.1382 & 1.98 (1.45 to 2.71$)$ & $<0.0001$ & 9.65 (4.74 to 19.6$)$ & $<0.0001$ \\
\hline Others & 6.64 (5.93 to 7.45$)$ & $<0.0001$ & 0.71 (0.63 to 0.79 ) & $<0.0001$ & 0.48 (0.32 to 0.73 ) & 0.0005 \\
\hline \multicolumn{7}{|l|}{ T stage } \\
\hline T0 & Reference & & Reference & & & \\
\hline $\mathrm{T} 1$ & 0.63 (0.37 to 1.09$)$ & 0.1007 & 1.39 (0.78 to 2.48$)$ & 0.2709 & Reference & \\
\hline $\mathrm{T} 2$ & $1.02(0.59$ to 1.75$)$ & 0.9435 & 1.74 (0.98 to 3.09$)$ & 0.0588 & 0.78 (0.61 to 1.00 ) & 0.0517 \\
\hline $\mathrm{T} 3$ & 1.28 (0.73 to 2.24$)$ & 0.3910 & 3.52 (1.94 to 6.39$)$ & $<0.0001$ & 0.75 (0.48 to 1.17 ) & 0.2040 \\
\hline T4 & 1.00 (0.58 to 1.70$)$ & 0.9861 & 1.65 (0.93 to 2.93 ) & 0.0862 & 0.20 (0.15 to 0.27 ) & $<0.0001$ \\
\hline Unknown & 0.74 (0.42 to 1.29$)$ & 0.2909 & 1.06 (0.58 to 1.92 ) & 0.8544 & 0.97 (0.46 to 2.03 ) & 0.9319 \\
\hline \multicolumn{7}{|l|}{ N stage } \\
\hline No & Reference & & Reference & & Reference & \\
\hline N1 & 2.72 (2.37 to 3.12 ) & $<0.0001$ & 1.07 (0.93 to 1.24$)$ & 0.34 & 0.97 (0.72 to 1.30$)$ & 0.8284 \\
\hline N2 & 2.22 (1.99 to 2.48$)$ & $<0.0001$ & $1.66(1.51$ to 1.82$)$ & $<0.0001$ & 0.13 (0.1 to 0.17$)$ & $<0.0001$ \\
\hline N3 & 2.36 (2.08 to 2.67$)$ & $<0.0001$ & $1.73(1.55$ to 1.92$)$ & $<0.0001$ & 0.02 (0.01 to 0.03 ) & $<0.0001$ \\
\hline Unknown & 1.05 (0.84 to 1.32 ) & 0.6623 & 0.68 (0.56 to 0.82 ) & $<0.0001$ & 0.28 (0.15 to 0.51$)$ & $<0.0001$ \\
\hline \multicolumn{7}{|l|}{ M stage } \\
\hline MO & Reference & & Reference & & Reference & \\
\hline M1 & 0.65 (0.6 to 0.71$)$ & $<0.0001$ & 0.35 (0.32 to 0.37$)$ & $<0.0001$ & 0.03 (0.02 to 0.04$)$ & $<0.0001$ \\
\hline Unknown & 0.29 (0.18 to 0.45$)$ & $<0.0001$ & 0.28 (0.20 to 0.39 ) & $<0.0001$ & 1.34 (0.61 to 2.92) & 0.4665 \\
\hline \multicolumn{7}{|l|}{ Laterality } \\
\hline Bilateral & Reference & & Reference & & Reference & \\
\hline Left & 0.62 (0.43 to 0.88 ) & 0.0071 & 3.46 (2.13 to 5.63$)$ & $<0.0001$ & 5.62 (0.69 to 45.6$)$ & 0.1063 \\
\hline Right & 0.56 (0.39 to 0.79$)$ & 0.0012 & 3.59 (2.21 to 5.83 ) & $<0.0001$ & 5.63 (0.69 to 45.6 ) & 0.1058 \\
\hline Unknown & $0.47(0.30$ to 0.74$)$ & 0.0012 & 1.82 (1.03 to 3.22$)$ & 0.0397 & & \\
\hline
\end{tabular}


Table 3 Multivariable Logistic regression for factors associated with surgery, chemotherapy, and radiation therapy in patients with lung cancer (Continued)

\begin{tabular}{|c|c|c|c|c|c|c|}
\hline \multirow[t]{2}{*}{ Variable } & \multicolumn{2}{|l|}{ Chemotherapy } & \multicolumn{2}{|l|}{ Radiation } & \multicolumn{2}{|l|}{ Surgery } \\
\hline & $\begin{array}{l}\text { Odds Ratio } \\
\text { (95\% Confidence Limit) }\end{array}$ & $P$ value & $\begin{array}{l}\text { Odds Ratio } \\
\text { (95\% Confidence Limit) }\end{array}$ & $P$ value & $\begin{array}{l}\text { Odds Ratio } \\
\text { (95\% Confidence Limit) }\end{array}$ & $P$ value \\
\hline \multicolumn{7}{|l|}{ Chemotherapy } \\
\hline 0 & & & Reference & & Reference & \\
\hline 1 & & & 1.21 (1.11 to 1.31$)$ & $<0.0001$ & 1.85 (1.45 to 2.35$)$ & $<0.0001$ \\
\hline \multicolumn{7}{|l|}{ Surgery type } \\
\hline Segmental & Reference & & Reference & & & \\
\hline Non-surgery & 1.32 (1.13 to 1.55$)$ & 0.0006 & 36.5 (29.3 to 45.48$)$ & $<0.0001$ & & \\
\hline Pneumonectomy & 1.80 (1.34 to 2.41$)$ & $<0.0001$ & 0.43 (0.20 to 0.95$)$ & 0.0363 & & \\
\hline \multicolumn{7}{|l|}{ Radiation } \\
\hline 0 & Reference & & & & Reference & \\
\hline 1 & 1.18 (1.08 to 1.28$)$ & 0.0001 & & & 0.05 (0.04 to 0.07$)$ & $<0.0001$ \\
\hline \multicolumn{7}{|l|}{ Immunotherapy } \\
\hline 0 & Reference & & Reference & & Reference & \\
\hline 1 & 4.06 (1.53 to 10.8$)$ & 0.0050 & 0.79 (0.29 to 2.1$)$ & 0.6303 & $0.02(0.00$ to 0.31$)$ & 0.0045 \\
\hline \multicolumn{7}{|l|}{ Institution type } \\
\hline Academic & Reference & & Reference & & Reference & \\
\hline Community & 0.81 (0.74 to 0.89 ) & $<0.0001$ & 0.90 (0.83 to 0.98$)$ & 0.0097 & 0.00 (0.00 to 0.01$)$ & $<0.0001$ \\
\hline \multicolumn{7}{|l|}{ Driving time (hours) } \\
\hline 1 & Reference & & Reference & & Reference & \\
\hline 2 & 0.88 (0.77 to 1.00$)$ & 0.0563 & 0.97 (0.86 to 1.1$)$ & 0.6531 & 1.93 (1.17 to 3.19$)$ & 0.0097 \\
\hline$>2$ & 0.92 (0.75 to 1.12$)$ & 0.4131 & 0.90 (0.74 to 1.08$)$ & 0.2578 & 1.05 (0.53 to 2.08) & 0.8908 \\
\hline \multicolumn{7}{|l|}{ Health Zone } \\
\hline Calgary & Reference & & Reference & & Reference & \\
\hline Central & 1.36 (1.19 to 1.56$)$ & $<0.0001$ & 0.75 (0.66 to 0.85 ) & $<0.0001$ & 5.21 (3.26 to 8.34 ) & $<0.0001$ \\
\hline Edmonton & 0.97 (0.89 to 1.06$)$ & 0.5263 & 0.99 (0.91 to 1.08$)$ & 0.8189 & 1.90 (1.52 to 2.36$)$ & $<0.0001$ \\
\hline North & 1.17 (0.95 to 1.44$)$ & 0.1448 & 0.94 (0.77 to 1.15$)$ & 0.5443 & 6.86 (3.40 to 13.85$)$ & $<0.0001$ \\
\hline South & 1.29 (1.10 to 1.52$)$ & 0.0019 & 0.92 (0.79 to 1.06$)$ & 0.2432 & 2.66 (1.38 to 5.16) & 0.0036 \\
\hline \multicolumn{7}{|l|}{ Education level $^{a}$} \\
\hline$<=80 \%$ & Reference & & Reference & & Reference & \\
\hline$>80 \%$ & 1.06 (0.98 to 1.15$)$ & 0.1557 & 1.00 (0.92 to 1.08$)$ & 0.9480 & 0.94 (0.75 to 1.18$)$ & 0.6046 \\
\hline \multicolumn{7}{|l|}{ Income level } \\
\hline$<=46 \mathrm{k}$ & Reference & & Reference & & Reference & \\
\hline$>46 \mathrm{k}$ & 1.21 (1.12 to 1.32$)$ & $<0.0001$ & 1.03 (0.95 to 1.11$)$ & 0.4565 & 1.35 (1.09 to 1.67$)$ & 0.0069 \\
\hline
\end{tabular}

CCI Charlson's comorbidity index, SCC Squamous cell cancer, SCLC Small cell lung cancer, LCNE Large Cell Neuroendocrine tumor. ${ }^{\mathrm{a}} 80 \%$ of residents have high school and above level of education in the neighborhood

CI, 1.00 to $1.02 ; P=0.0489 ; 61-70$ years: $\mathrm{HR}, 1.11 ; 95 \%$ CI, 1.04 to $1.19 ; P=0.0017 ; 71-80$ years: $\mathrm{HR}, 1.08 ; 95 \%$ CI, 1.02 to $1.14 ; P=0.0099$; $>80$ years: HR, 1.11 ; $95 \% \mathrm{CI}$, 1.03 to $1.20 ; P=0.0067)$ as well as $\mathrm{OS}(<60$ years: $\mathrm{HR}$, 1.14 ; $95 \% \mathrm{CI}, 1.04$ to $1.25 ; P=0.0059 ; 61-70$ years: $\mathrm{HR}$, 1.16 ; $95 \% \mathrm{CI}, 1.08$ to $1.23 ; P<0.0001 ; 71-80$ years: $\mathrm{HR}$, $1.14 ; 95 \% \mathrm{CI}, 1.08$ to $1.20 ; P<0.0001$; $>80$ years: $\mathrm{HR}$, 1.15 ; $95 \% \mathrm{CI}, 1.07$ to $1.23 ; P<0.0001)$ in all age groups.

The presence of pre-existing cardiovascular disease can alter the effect of various treatments on the outcomes of patients with lung cancer. Therefore, we assessed for any effect modification by examining interactions in the statistical models. The effect of baseline cardiovascular disease on OS varied for chemotherapy $(P=0.026)$, surgery $(P<0.0001)$, and radiotherapy $(P=0.001)$. Likewise, for CSS, the interactions were significant for radiotherapy and surgery $(P=0.050$, and $P=$ 0.001 , respectively). However, the interaction of chemotherapy on CSS showed only a trend towards significance $(P=0.060)$.

Finally, in the competing risk multistate model adjusted for baseline characteristics, we found that presence of cardiovascular disease was associated with an increased risk of non-cancer related death (HR, 1.48; 


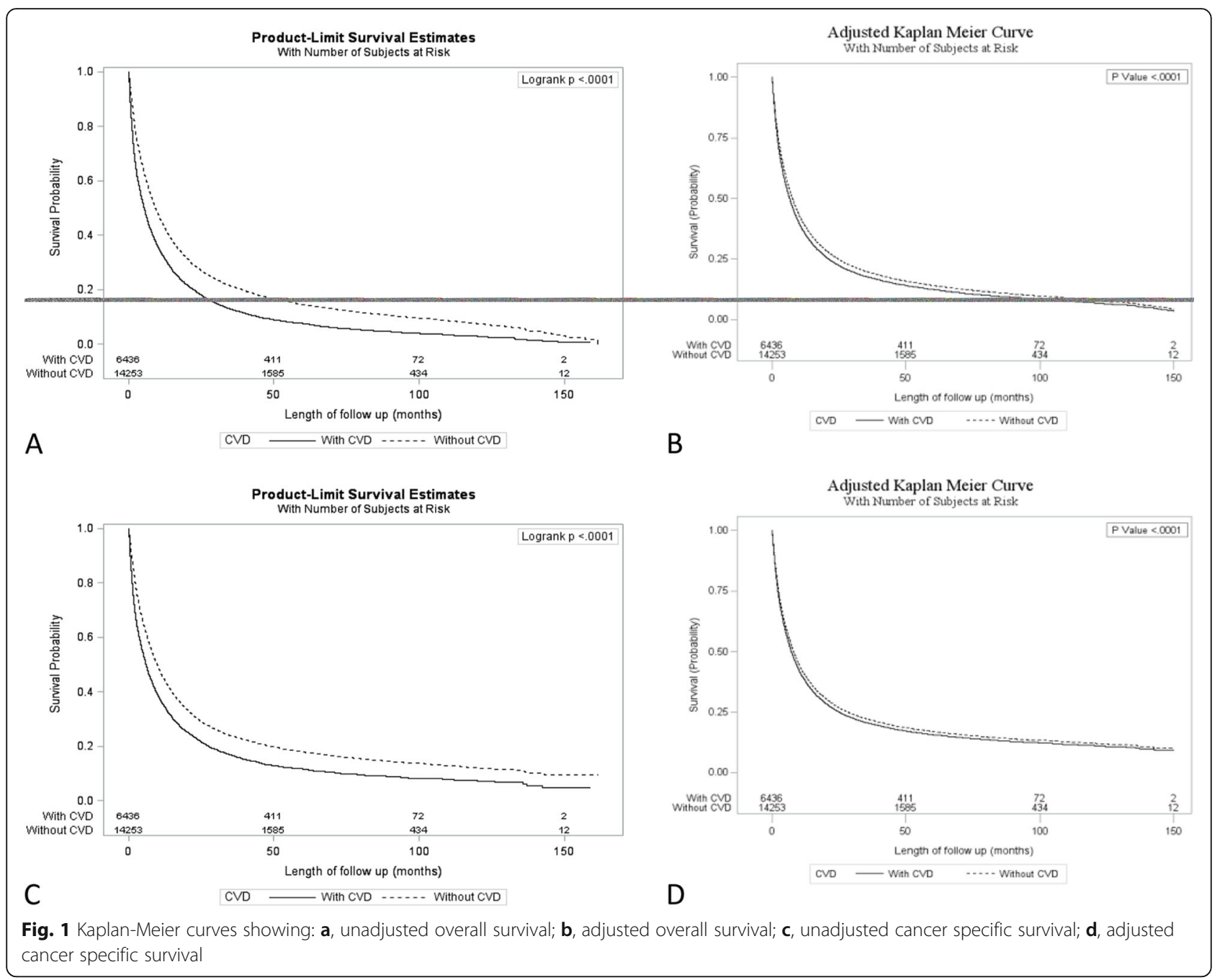

95\% CI, 1.33-1.64; $P<0.0001)$ but not cancer related death (HR, 0.98; 95\% CI, 0.94-1.03; $P=0.460$ ) (Table 5).

\section{Discussion}

In this large study of over 20,000 patients that included patients across all stages of lung cancer, approximately one-third of patients had pre-existing cardiovascular disease, most commonly congestive heart failure. The presence of baseline heart disease was associated with a lower likelihood of receiving any form of cancer treatment including chemotherapy, radiotherapy or surgery. Further, pre-existing cardiovascular disease in patients with lung cancer predicted for inferior survival OS and CSS. Presence of cardiovascular disease was associated with increased non-cancer related deaths but not cancer related deaths in the multistate model. This suggests that the excess mortality in patients with cardiovascular disease and lung cancer was related to the increased risk of non-cancer related deaths.
A previous study from the United States linking the Surveillance, Epidemiology, and End Results data and Medicare (SEER) data reported on the effect of cardiovascular disease on survival outcomes in patients with non-small cell lung cancer. Ischemic heart disease (33.7\%), cardiac arrythmias (28.6\%), and congestive heart failure $(17.5 \%)$ were the common cardiovascular diseases reported in that study [23]. The corresponding prevalence of these conditions in our study were lower at $10.3,9.4$, and $14.7 \%$, respectively. One potential reason for this difference is that the age group of patients across studies were remarkably different. While older age was not an exclusion criterion and $21.5 \%$ of patients were less than 60 years old in the current study, those less than 65 years were excluded from the study in the United States. Moreover, a lower frequency of obesity and cigarette smoking in Canadians as compared with Americans may be another factor contributing to the observed differences in cardiovascular diseases [26, 27]. 
Table 4 Multivariable Cox regression model for factors associated with overall survival and cancer-specific survival in patients with lung cancer

\begin{tabular}{|c|c|c|c|c|}
\hline \multirow[t]{2}{*}{ Variable } & \multicolumn{2}{|l|}{ Overall survival } & \multicolumn{2}{|l|}{ Cancer specific survival } \\
\hline & HR ( $95 \%$ Confidence Limit) & $P$ value & HR ( $95 \%$ Confidence Limit) & $P$ value \\
\hline \multicolumn{5}{|l|}{ Age group } \\
\hline$<=60$ & Reference & & Reference & \\
\hline $61-70$ & $1.1(1$ to 1.1$)$ & 0.0005 & $1.1(1$ to 1.1$)$ & 0.0061 \\
\hline $71-80$ & $1.1(1$ to 1.1$)$ & 0.0012 & 1 (1 to 1.1$)$ & 0.2039 \\
\hline$>80$ & $1.1(1.1$ to 1.2$)$ & $<0.0001$ & $1.1(1$ to 1.1$)$ & 0.0037 \\
\hline \multicolumn{5}{|l|}{ Sex } \\
\hline Female & Reference & & Reference & \\
\hline Male & $1.2(1.2$ to 1.2$)$ & $<0.0001$ & $1.2(1.2$ to 1.2$)$ & $<0.0001$ \\
\hline Year of diagnosis & 1 (1 to 1$)$ & 0.0012 & $1(1$ to 1$)$ & 0.1635 \\
\hline \multicolumn{5}{|l|}{$\mathrm{CCl}$ score } \\
\hline 0 & Reference & & Reference & \\
\hline 1 & 1 (0.9 to 1$)$ & 0.2999 & $1(0.9$ to 1$)$ & 0.145 \\
\hline$>1$ & $1.2(1.1$ to 1.2$)$ & $<0.0001$ & $1.2(1.1$ to 1.2$)$ & $<0.0001$ \\
\hline \multicolumn{5}{|c|}{ Cardiovascular disease } \\
\hline Yes & Reference & & Reference & \\
\hline No & 1.1 (1.1 to 1.2$)$ & $<0.0001$ & $1.1(1.1$ to 1.1$)$ & $<0.0001$ \\
\hline \multicolumn{5}{|l|}{ Histology } \\
\hline Adenocarcinoma & Reference & & Reference & \\
\hline SCC & $1.1(1$ to 1.1$)$ & 0.0182 & 1 (1 to 1.1$)$ & 0.2506 \\
\hline $\mathrm{SCLC}$ & 1.6 (1.5 to 1.7$)$ & $<0.0001$ & 1.6 (1.5 to 1.7$)$ & $<0.0001$ \\
\hline Carcinoid/LCNE & 0.7 (0.7 to 0.8) & $<0.0001$ & $0.8(0.7$ to 0.9$)$ & $<0.0001$ \\
\hline Large cell ca & 1.3 (1.1 to 1.4$)$ & 0.0011 & 1.3 (1.1 to 1.5$)$ & 0.0005 \\
\hline Others & 1.2 (1.2 to 1.3 ) & $<0.0001$ & $1.2(1.2$ to 1.3$)$ & $<0.0001$ \\
\hline \multicolumn{5}{|l|}{ T stage } \\
\hline T0 & Reference & & Reference & \\
\hline $\mathrm{T} 1$ & 1.3 (1 to 1.6) & 0.0394 & 1.1 (0.9 to 1.4$)$ & 0.2457 \\
\hline $\mathrm{T} 2$ & 1.8 (1.5 to 2.3 ) & $<0.0001$ & 1.8 (1.4 to 2.2 ) & $<0.0001$ \\
\hline T3 & 2.5 (2 to 3.1$)$ & $<0.0001$ & 2.4 (1.9 to 3 ) & $<0.0001$ \\
\hline $\mathrm{T} 4$ & 2.6 (2.1 to 3.2$)$ & $<0.0001$ & 2.5 (2 to 3.1$)$ & $<0.0001$ \\
\hline Unknown & 1.8 (1.4 to 2.2 ) & $<0.0001$ & 1.7 (1.4 to 2.2 ) & $<0.0001$ \\
\hline \multicolumn{5}{|l|}{$\mathrm{N}$ stage } \\
\hline No & Reference & & Reference & \\
\hline N1 & 1.4 (1.3 to 1.5$)$ & $<0.0001$ & 1.5 (1.4 to 1.6$)$ & $<0.0001$ \\
\hline N2 & 1.8 (1.7 to 1.8$)$ & $<0.0001$ & 1.9 (1.8 to 1.9$)$ & $<0.0001$ \\
\hline N3 & $1.8(1.7$ to 1.9$)$ & $<0.0001$ & 1.9 (1.8 to 2$)$ & $<0.0001$ \\
\hline Unknown & 1.6 (1.5 to 1.7$)$ & $<0.0001$ & 1.7 (1.5 to 1.8$)$ & $<0.0001$ \\
\hline \multicolumn{5}{|l|}{ M stage } \\
\hline MO & Reference & & Reference & \\
\hline M1 & 1.9 (1.8 to 1.9 ) & $<0.0001$ & 2 (1.9 to 2.1$)$ & $<0.0001$ \\
\hline Unknown & 0.9 (0.8 to 1$)$ & 0.2007 & 0.9 (0.8 to 1.1$)$ & 0.2776 \\
\hline
\end{tabular}


Table 4 Multivariable Cox regression model for factors associated with overall survival and cancer-specific survival in patients with lung cancer (Continued)

\begin{tabular}{|c|c|c|c|c|}
\hline \multirow[t]{2}{*}{ Variable } & \multicolumn{2}{|l|}{ Overall survival } & \multicolumn{2}{|l|}{ Cancer specific survival } \\
\hline & HR (95\% Confidence Limit) & $P$ value & HR (95\% Confidence Limit) & $P$ value \\
\hline \multicolumn{5}{|l|}{ Lateral } \\
\hline Bilateral & Reference & & Reference & \\
\hline Left & $1.3(1.1$ to 1.5$)$ & 0.0001 & $1.3(1.1$ to 1.5$)$ & 0.0014 \\
\hline Right & 1.3 (1.2 to 1.5$)$ & $<0.0001$ & $1.3(1.1$ to 1.5$)$ & 0.0005 \\
\hline Unknown & $2(1.7$ to 2.4$)$ & $<0.0001$ & 1.9 (1.6 to 2.3$)$ & $<0.0001$ \\
\hline \multicolumn{5}{|l|}{ Surgery type } \\
\hline Pneumonectomy & Reference & & Reference & \\
\hline Lobectomy or segmental & 0.7 (0.6 to 0.9$)$ & 0.0002 & 0.6 (0.5 to 0.8$)$ & $<0.0001$ \\
\hline Non-surgery & $2.8(2.4$ to 3.3$)$ & $<0.0001$ & 2.7 (2.3 to 3.3$)$ & $<0.0001$ \\
\hline \multicolumn{5}{|l|}{ Chemotherapy } \\
\hline No & Reference & & Reference & \\
\hline Yes & $0.4(0.4$ to 0.4$)$ & $<0.0001$ & $0.4(0.4$ to 0.4$)$ & $<0.0001$ \\
\hline \multicolumn{5}{|l|}{ Radiation } \\
\hline No & Reference & & Reference & \\
\hline Yes & 0.6 (0.6 to 0.7$)$ & $<0.0001$ & 0.6 (0.6 to 0.7$)$ & $<0.0001$ \\
\hline \multicolumn{5}{|l|}{ Surgery institution type } \\
\hline Academic & Reference & & Reference & \\
\hline Community & 1 (1 to 1.1$)$ & 0.44 & 1 (1 to 1.1$)$ & 0.069 \\
\hline \multicolumn{5}{|l|}{ Driving time (hours) } \\
\hline 1 & Reference & & Reference & \\
\hline 2 & 1 (1 to 1.1$)$ & 0.5613 & 1 (1 to 1.1$)$ & 0.4693 \\
\hline 3 & 0.9 (0.8 to 1$)$ & 0.0215 & 0.9 (0.8 to 1$)$ & 0.0073 \\
\hline \multicolumn{5}{|l|}{ Zone name } \\
\hline Calgary & Reference & & Reference & \\
\hline Central & 1.1 (1 to 1.1$)$ & 0.004 & 1.1 (1 to 1.1$)$ & 0.03 \\
\hline Edmonton & 1.1 (1 to 1.1) & $<0.0001$ & $1.1(1.1$ to 1.1$)$ & $<0.0001$ \\
\hline North & 1.2 (1.1 to 1.3$)$ & $<0.0001$ & $1.2(1.1$ to 1.3$)$ & $<0.0001$ \\
\hline South & $1.2(1.1$ to 1.3$)$ & $<0.0001$ & $1.2(1.1$ to 1.3$)$ & $<0.0001$ \\
\hline \multicolumn{5}{|l|}{ Education level $^{a}$} \\
\hline$<=80 \%$ & Reference & & Reference & \\
\hline$>80 \%$ & 1 (1 to 1$)$ & 0.3769 & 1 (1 to 1$)$ & 0.5999 \\
\hline \multicolumn{5}{|l|}{ Income level } \\
\hline$<=46 \mathrm{k}$ & Reference & & Reference & \\
\hline$>46 k$ & 1 (1 to 1 ) & 0.9992 & 1 (1 to 1$)$ & 0.8051 \\
\hline
\end{tabular}

CCI Charlson's comorbidity index, SCC Squamous cell cancer, SCLC Small cell lung cancer, LCNE Large Cell Neuroendocrine tumor. ${ }^{\mathrm{a}} 80 \%$ of residents have high school and above level of education in the neighborhood

The prevalence of baseline cardiovascular disease in patients with breast cancer was as low as $8 \%$ in a prior Canadian study [21]. However, that study included women exclusively and the median age of patients was 59 years. The higher prevalence of cardiovascular disease in this study may reflect the larger proportion of older males in the current study cohort [28]. Notably, the pattern of cardiovascular diseases was also different. For instance, cerebrovascular accidents (2.6\%) and cardiac arrythmias $(2.0 \%)$ were more common than heart failure $(1.8 \%)$ and myocardial infarction (1.1\%) in women with breast cancer. Conversely, heart failure (14.7\%) and cerebrovascular accidents (12.5\%) were more prevalent than myocardial infarction (10.3\%) and cardiac arrythmias 
Table 5 Competing risk multistate model

\begin{tabular}{|c|c|c|c|c|}
\hline \multirow[t]{2}{*}{ Variable } & \multicolumn{2}{|l|}{ Cancer related death } & \multicolumn{2}{|l|}{ Non-cancer related death } \\
\hline & HR ( $95 \%$ Confidence Limit) & $P$ value & HR (95\% Confidence Limit) & $P$ value \\
\hline \multicolumn{5}{|l|}{ Age group } \\
\hline$<=60$ & Reference & & & \\
\hline $61-70$ & $1.05(1.00-1.10)$ & 0.074 & $1.24(1.05-1.46)$ & 0.010 \\
\hline $71-80$ & $1.01(0.96-1.06)$ & 0.760 & $1.60(1.36-1.88)$ & $<0.0001$ \\
\hline$>80$ & $1.07(1.00-1.14)$ & 0.037 & $1.34(1.10-1.63)$ & 0.004 \\
\hline \multicolumn{5}{|l|}{ Sex } \\
\hline Male & Reference & & & \\
\hline Female & $0.89(0.85-0.92)$ & $<0.0001$ & $0.95(0.87-1.05)$ & 0.340 \\
\hline Year of diagnosis & $0.98(0.98-0.99)$ & $<0.0001$ & $1.06(1.05-1.08)$ & $<0.0001$ \\
\hline \multicolumn{5}{|l|}{$\mathrm{CCl}$ score } \\
\hline 0 & Reference & & & \\
\hline 1 & $0.95(0.89-1.02)$ & 0.140 & $1.07(0.88-1.31)$ & 0.480 \\
\hline 2 & $1.11(1.05-1.17)$ & 0.001 & $1.10(0.94-1.30)$ & 0.250 \\
\hline \multicolumn{5}{|l|}{ CVD } \\
\hline Without CVD & Reference & & & \\
\hline With CVD & $0.98(0.94-1.03)$ & 0.460 & $1.48(1.33-1.64)$ & $<0.0001$ \\
\hline \multicolumn{5}{|l|}{ Grade } \\
\hline 1 & Reference & & & \\
\hline 2 & $1.43(1.25-1.63)$ & $<0.0001$ & $1.18(0.91-1.53)$ & 0.220 \\
\hline 3 & $1.71(1.51-1.94)$ & $<0.0001$ & $1.02(0.78-1.34)$ & 0.870 \\
\hline Unknown & $1.53(1.35-1.73)$ & $<0.0001$ & $1.10(0.84-1.44)$ & 0.480 \\
\hline \multicolumn{5}{|l|}{ Histology } \\
\hline Adenocarcinoma & Reference & & & \\
\hline Carcinoid/LCNE & $0.83(0.72-0.96)$ & 0.011 & $0.83(0.59-1.167)$ & 0.280 \\
\hline Large cell ca & $1.19(1.01-1.41)$ & 0.036 & $0.80(0.49-1.321)$ & 0.390 \\
\hline Others & $1.18(1.12-1.24)$ & $<0.0001$ & $0.83(0.72-0.949)$ & 0.007 \\
\hline SCC & $1.00(0.96-1.06)$ & 0.780 & $1.16(1.02-1.323)$ & 0.030 \\
\hline SCLC & $1.40(1.31-1.49)$ & $<0.0001$ & $0.96(0.79-1.17)$ & 0.700 \\
\hline \multicolumn{5}{|l|}{ T stage } \\
\hline T0 & Reference & & & \\
\hline $\mathrm{T} 1$ & $1.06(0.79-1.42)$ & 0.680 & $1.32(0.50-3.47)$ & 0.570 \\
\hline $\mathrm{T} 2$ & $1.54(1.16-2.06)$ & 0.003 & $1.06(0.40-2.77)$ & 0.910 \\
\hline T3 & $1.94(1.44-2.62)$ & $<0.0001$ & $0.86(0.32-2.32)$ & 0.760 \\
\hline $\mathrm{T} 4$ & $2.04(1.53-2.72)$ & $<0.0001$ & $0.78(0.30-2.05)$ & 0.620 \\
\hline Unknown & $1.48(1.10-1.99)$ & 0.010 & $1.14(0.43-2.99)$ & 0.800 \\
\hline \multicolumn{5}{|l|}{$\mathrm{N}$ stage } \\
\hline NO & Reference & & & \\
\hline N1 & $1.38(1.29-1.48)$ & $<0.0001$ & $0.80(0.67-0.95)$ & 0.011 \\
\hline N2 & $1.69(1.61-1.78)$ & $<0.0001$ & $0.53(0.46-0.61)$ & $<0.0001$ \\
\hline N3 & $1.73(1.63-1.84)$ & $<0.0001$ & $0.56(0.46-0.67)$ & $<0.0001$ \\
\hline Unknown & $1.45(1.31-1.60)$ & $<0.0001$ & $0.87(0.68-1.11)$ & 0.250 \\
\hline
\end{tabular}


Table 5 Competing risk multistate model (Continued)

\begin{tabular}{|c|c|c|c|c|}
\hline \multirow[t]{2}{*}{ Variable } & \multicolumn{2}{|l|}{ Cancer related death } & \multicolumn{2}{|l|}{ Non-cancer related death } \\
\hline & HR (95\% Confidence Limit) & $P$ value & HR (95\% Confidence Limit) & $P$ value \\
\hline \multicolumn{5}{|l|}{ M stage } \\
\hline M0 & Reference & & & \\
\hline M1 & $1.88(1.80-1.96)$ & $<0.0001$ & $0.46(0.40-0.52)$ & $<0.0001$ \\
\hline Unknown & $0.89(0.76-1.04)$ & 0.160 & $1.13(0.79-1.62)$ & 0.510 \\
\hline \multicolumn{5}{|l|}{ Lateral } \\
\hline Bilateral & Reference & & & \\
\hline Left & $1.05(0.88-1.26)$ & 0.570 & $1.06(0.56-1.99)$ & 0.870 \\
\hline Right & $1.06(0.89-1.28)$ & 0.490 & $0.99(0.53-1.88)$ & 0.990 \\
\hline Unknown & $1.52(1.21-1.90)$ & $<0.0001$ & $0.97(0.45-2.10)$ & 0.940 \\
\hline \multicolumn{5}{|l|}{ Surgery type } \\
\hline No surgery & Reference & & & \\
\hline Lobectomy or segmental & $0.32(0.30-0.35)$ & $<0.0001$ & $0.72(0.59-0.88)$ & 0.002 \\
\hline Pneumonectomy & $0.48(0.40-0.57)$ & $<0.0001$ & $0.73(0.48-1.13)$ & 0.160 \\
\hline \multicolumn{5}{|l|}{ Chemotherapy } \\
\hline 0 & Reference & & & \\
\hline 1 & $0.47(0.45-0.49)$ & $<0.0001$ & $1.14(1.00-1.30)$ & 0.047 \\
\hline \multicolumn{5}{|l|}{ Radiation } \\
\hline 0 & Reference & & & \\
\hline 1 & $0.74(0.71-0.77)$ & $<0.0001$ & $0.90(0.80-1.02)$ & 0.110 \\
\hline \multicolumn{5}{|l|}{ Immunotherapy } \\
\hline 0 & Reference & & & \\
\hline 1 & $0.52(0.32-0.85)$ & 0.010 & $1.44(0.33-6.31)$ & 0.620 \\
\hline \multicolumn{5}{|l|}{ Surgery institution type } \\
\hline Academic & Reference & & & \\
\hline Community & $1.07(1.03-1.12)$ & 0.002 & $0.72(0.63-0.83)$ & $<0.0001$ \\
\hline \multicolumn{5}{|c|}{ Driving time to the nearest cancer center (hours) } \\
\hline 1 & Reference & & & \\
\hline 2 & $1.06(0.99-1.13)$ & 0.074 & $0.94(0.79-1.11)$ & 0.440 \\
\hline$>2$ & $0.88(0.79-0.97)$ & 0.013 & $1.15(0.89-1.49)$ & 0.290 \\
\hline \multicolumn{5}{|l|}{ Zone name } \\
\hline Calgary & Reference & & & \\
\hline Central & $1.02(0.95-1.09)$ & 0.640 & $1.22(1.02-1.46)$ & 0.030 \\
\hline Edmonton & $1.09(1.04-1.14)$ & 0.001 & $0.84(0.74-0.96)$ & 0.009 \\
\hline North & $1.19(1.07-1.32)$ & 0.001 & $1.02(0.77-1.34)$ & 0.910 \\
\hline South & $1.10(1.02-1.20)$ & 0.019 & $1.15(0.93-1.43)$ & 0.190 \\
\hline \multicolumn{5}{|l|}{ Educational level $^{\mathrm{a}}$} \\
\hline$<=80 \%$ & Reference & & & \\
\hline$>80 \%$ & $1.00(0.96-1.04)$ & 0.950 & $0.96(0.86-1.07)$ & 0.480 \\
\hline \multicolumn{5}{|l|}{ Income level } \\
\hline$<=46 \mathrm{k}$ & Reference & & & \\
\hline$>46 k$ & $1.02(0.98-1.06)$ & 0.430 & $0.92(0.82-1.03)$ & 0.160 \\
\hline
\end{tabular}

CCI Charlson's comorbidity index, SCC Squamous cell cancer, SCLC Small cell lung cancer, LCNE Large Cell Neuroendocrine tumor. ${ }^{\text {a }} 80 \%$ of residents have high school and above level of education in the neighborhood 
(9.4\%) in patients with lung cancer. The drivers of these differences are likely multifactorial, but one factor could be the role of estrogen in preventing ischemic heart disease in younger women. Another reason could be differences in modifiable risk factors, such as smoking and obesity, between men and women [28, 29].

As expected, patients with baseline cardiovascular disease were less likely to receive any form of treatment for lung cancer. This finding was observed across all age groups, except for chemotherapy in patients older than 80 years. It is likely that a proportion of these patients were considered unfit to receive therapy, in which case their lack of treatment is clinically appropriate. However, we hypothesized that others may have been denied treatment because of perceived concerns that their cardiovascular comorbidity may place them at heightened risk of toxicities or because of the absence of data from clinical trials regarding the safety of chemotherapy administration in patients with heart disease [30]. It has been reported that heart disease represents the second most common cause of ineligibility for clinical trials [31, 32]. This results in limited data to guide oncologists when they treat comorbid patients in the real-world and contributes to variations in management whereby physicians base their decisions on anecdotal experience. It is likely in these scenarios that physicians resort to the use of patient-related factors such as age and performance status, as well as the expertise of cardio-oncologists in formulating their treatment plans [33, 34]. Broadening of eligibility criteria in clinical trials to represent patients with a history of cardiovascular disease will increase the generalizability of results to real-world patients and optimize evidence-based treatment in this subpopulation.

Our study found that the OS of patients with lung cancer who had baseline cardiovascular disease were worse compared to those without pre-existing cardiac comorbid conditions. Similar findings were reported in the SEER and Medicare linked study from the United States of older beneficiaries [23]. Another small study of 247 patients with limited stage lung cancer also showed increased postoperative morbidity and mortality among patients with lung cancer and pre-existing cardiovascular disease [22]. Importantly, inferior OS were also reported in a large Canadian study of patients with breast cancer and baseline cardiovascular disease, suggesting that this observation may persist across different tumor types [21].

Interestingly, we found that prior cardiovascular disease was associated with an increased risk of noncancer related death but not cancer related death in the competing risk multistate model. However, patients with cardiovascular disease had worse CSS when competing risks were not used in the Cox model. This finding highlights the previously reported overestimation of cancer-specific deaths in time-toevent analysis where non-cancer specific deaths are censored, especially among patients with comorbidities. In such models, patients who die of unrelated causes are censored at death and wrongly assumed to have had the same probability of cancer related death compared to those who continue with follow-up [35]. Therefore, a competing risk model is generally considered more appropriate when patients have other competing risks of death. This is particularly true for patients with lung cancer who are likely to be older and may be afflicted with other pulmonary or cardiac conditions that can represent a serious threat to their overall health $[19,20]$.

The management of lung cancer is experiencing a significant paradigm shift with the recent approvals of various targeted therapies and immune checkpoint inhibitors, all of which have demonstrated improved survival across different subsets of patients with lung cancer [36-40]. In this study, patients with pre-existing cardiovascular disease were less likely to receive immunotherapy, although only 20 patients received checkpoint inhibitors in our cohort. The use of novel immunotherapeutic agents in patients with lung cancer is increasing after they were approved in Canada in 2016 [41, 42]. Since one-third of patients with lung cancer were found to have associated cardiovascular disease, it is imperative that early cardio-oncology consultations be sought in such patients to optimize the concurrent management of comorbid conditions so that the benefit of novel therapies can be extended to these patients in the real-world.

The study was limited by its retrospective design and use of administrative sources for data. Therefore, the clinical severity of cardiovascular disease and performance status could not be ascertained reliably. Further, data on other associated characteristics, such as smoking and body mass index, were not available. These factors could potentially act as confounders and it may be possible that the treatment patterns and survival outcomes in patients with lung cancer could vary based on such factors. Lastly, the presence of cardiovascular disease was assumed as the reason for not receiving treatment, even though additional factors such as patient preference and physician discretion are major contributors to treatment decisions. However, the large sample size of our study and the population-based nature of the data are major strengths.

\section{Conclusions}

In summary, a significant proportion of patients with lung cancer have baseline cardiovascular disease, which is associated with a lower likelihood of receiving any cancer treatment and also a higher risk of cancer-related 
death. With a plethora of novel therapies being developed, early engagement and co-management with experts in cardio-oncology can help to optimize the number of lung cancer patients who can derive benefit from emerging therapies.

\section{Supplementary information}

Supplementary information accompanies this paper at https://doi.org/10. 1186/s12885-020-07487-9.

Additional file 1: Supplemental Table 1. Histology stratified logistic regression to predict the likelihood of treatment (A: Chemotherapy, B: Radiotherapy, C: Surgery). Supplemental Table 2. Age stratified logistic regression analysis to predict the likelihood of treatment ( $A$ : Chemotherapy, B: Radiotherapy, C: Surgery).

\section{Abbreviations}

ACR: Alberta Cancer Registry; ICD-10: International Classification of Diseases tenth version; OS: Overall Survival; CSS: Cancer Specific Survival; Cl: Confidence Interval; OR: Odds Ratio; HR: HR

\section{Acknowledgements}

None.

\section{Authors' contributions}

All authors have read and approved the final manuscript. $A B$ : Conceptualization, data collection and analysis, writing- original draft, editing. DS: Data collection, writing. SK: Data collection and analysis. WC: Conceptualization, data collection and analysis, writing-reviewing and editing, editing, supervision.

\section{Funding}

This research did not receive any specific grant from funding agencies in the public, commercial, or not-for-profit sectors.

\section{Availability of data and materials}

The datasets used and/or analysed during the current study are available from the corresponding author on reasonable request.

\section{Ethics approval and consent to participate}

Institutional approval was obtained from the Health Research Ethics Board of Alberta's Cancer Committee to access, use, and analyse the clinical data for this study. Because this represented a secondary use of retrospective data for which identifiers were removed, waiver of consent was granted.

\section{Consent for publication}

Not applicable.

\section{Competing interests}

The authors declare that they have no competing interests" in this section.

Received: 3 May 2020 Accepted: 2 October 2020

Published online: 15 October 2020

\section{References}

1. Cardiovascular diseases. [cited 2020 Mar 22]. Available from: https://www. who.int/westernpacific/health-topics/cardiovascular-diseases.

2. Cancer [Internet]. [cited 2020 Mar 12]. Available from: https://www.who.int/ news-room/fact-sheets/detail/cancer.

3. GBD 2016 Causes of Death Collaborators. Global, regional, and national agesex specific mortality for 264 causes of death, 1980-2016: a systematic analysis for the Global Burden of Disease Study 2016. Lancet. 2017; 390(10100):1151-210.

4. Dawber TR, Kannel WB, Revotskie N, Stokes J, Kagan A, Gordon T. Some factors associated with the development of coronary heart disease: six years' follow-up experience in the Framingham study. Am J Public Health Nations Health. 1959;49:1349-56.
5. Masoudkabir F, Sarrafzadegan N, Gotay C, Ignaszewski A, Krahn AD, Davis MK, et al. Cardiovascular disease and cancer: evidence for shared disease pathways and pharmacologic prevention. Atherosclerosis. 2017;263:343-51.

6. Ligibel JA, Alfano CM, Courneya KS, Demark-Wahnefried W, Burger RA, Chlebowski RT, et al. American Society of Clinical Oncology position statement on obesity and cancer. J Clin Oncol. 2014;32(31):3568-74.

7. Tourmousoglou CE, Apostolakis E, Dougenis D. Simultaneous occurrence of coronary artery disease and lung cancer: what is the best surgical treatment strategy? Interact Cardiovasc Thorac Surg. 2014;19(4):673-81.

8. Kreatsoulas C, Anand SS, Subramanian SV. An emerging double burden of disease: the prevalence of individuals with cardiovascular disease and cancer. J Intern Med. 2014;275(5):494-505.

9. Inohara T, Endo A, Melloni C. Unmet needs in managing myocardial infarction in patients with malignancy. Front Cardiovasc Med. 2019;6:57

10. Blaes $\mathrm{AH}$, Shenoy $\mathrm{C}$. Is it time to include cancer in cardiovascular risk prediction tools? Lancet. 2019;394(10203):986-8.

11. Alberg AJ, Samet JM. Epidemiology of lung cancer. Chest. 2003;123(1 Suppl):21S-49S

12. Kamp DW, Shacter E, Weitzman SA. Chronic inflammation and cancer: the role of the mitochondria. Oncology (Williston Park, NY). 2011;25(5):400-10 413.

13. Barrera G. Oxidative stress and lipid peroxidation products in cancer progression and therapy. ISRN Oncol. 2012;2012:137289.

14. Tesfamariam B, Cohen RA. Free radicals mediate endothelial cell dysfunction caused by elevated glucose. Am J Phys. 1992;263(2 Pt 2):H321-6.

15. Cancer of the Lung and Bronchus - Cancer Stat Facts. SEER. [cited 2019 Nov 19]. Available from: https://seer.cancer.gov/statfacts/html/lungb.html.

16. Lloyd-Jones D, Adams R, Carnethon M, De Simone G, Ferguson TB, Flegal K, et al. Heart disease and stroke statistics--2009 update: a report from the American Heart Association statistics committee and stroke statistics subcommittee. Circulation. 2009;119(3):e21-181.

17. Vyskočil J, Petráková K, Jelínek P, Furdek M. Cardiovascular complications of cancers and anti-cancer therapy. Vnitr Lek. 2017;63(3):200-9.

18. Daher IN, Daigle TR, Bhatia N, Durand J-B. The prevention of cardiovascular disease in Cancer survivors. Tex Heart Inst J. 2012;39(2):190-8.

19. Al-Kindi SG, Oliveira GH. Prevalence of preexisting cardiovascular disease in patients with different types of Cancer: the unmet need for Oncocardiology. Mayo Clin Proc. 2016;91(1):81-3.

20. Liu D, Ma Z, Yang J, Zhao M, Ao H, Zheng $X$, et al. Prevalence and prognosis significance of cardiovascular disease in cancer patients: a population-based study. Aging (Albany NY). 2019;11(18):7948-60.

21. Abdel-Rahman O, Xu Y, Kong S, Dort J, Quan ML, Karim S, et al. Impact of baseline cardiovascular comorbidity on outcomes in women with breast Cancer: a real-world, Population-based Study. Clin Breast Cancer. 2019;19(2): e297-305.

22. Ambrogi V, Pompeo E, Elia S, Pistolese GR, Mineo TC. The impact of cardiovascular comorbidity on the outcome of surgery for stage I and II non-small-cell lung cancer. Eur J Cardiothorac Surg. 2003 May 1;23(5):811-7.

23. Kravchenko J, Berry M, Arbeev K, Lyerly HK, Yashin A, Akushevich I. Cardiovascular comorbidities and survival of lung cancer patients: Medicare data based analysis. Lung Cancer. 2015;88(1):85-93.

24. Quan H, Sundararajan V, Halfon P, Fong A, Burnand B, Luthi J-C, et al. Coding algorithms for defining comorbidities in ICD-9-CM and ICD-10 administrative data. Med Care. 2005:43(11):1130-9.

25. Ambroggi M, Biasini C, Del Giovane C, Fornari F, Cavanna L. Distance as a barrier to Cancer diagnosis and treatment: review of the literature. Oncologist. 2015;20(12):1378-85.

26. Jones A, Gulbis A, Baker EH. Differences in tobacco use between Canada and the United States. Int J Public Health. 2010;55(3):167-75.

27. Shields M, Carroll MD, Ogden CL. Adult obesity prevalence in Canada and the United States. NCHS Data Brief. 2011;56:1-8.

28. Robitaille C, McRae L, Toews J. Monitoring the burden of heart disease with the canadian chronic disease surveillance system. Can J Cardiol. 2017;33(10): S138-9.

29. Möller-Leimkühler AM. Gender differences in cardiovascular disease and comorbid depression. Dialogues Clin Neurosci. 2007;9(1):71-83.

30. Booton R, Jones M, Thatcher N. Lung cancer - 7: management of lung cancer in elderly patients. Thorax. 2003;58(8):711-20.

31. Karim S, Xu Y, Kong S, Abdel-Rahman O, Quan ML, Cheung WY. Generalisability of common oncology clinical trial eligibility criteria in the real world. Clin Oncol. 2019;31(9):e160-6. 
32. Batra A, Kong S, Cheung WY. Eligibility of real-world patients with stage II and III colon cancer for adjuvant chemotherapy trials. Clin Colorectal Cancer. 2020; 26 [cited 2020 Jun 2]; Available from: http://www. sciencedirect.com/science/article/pii/S1533002820300785.

33. Coviello JS. Cardiovascular and Cancer risk: the role of cardio-oncology. J Adv Pract Oncol. 2018;9(2):160-76.

34. Fradley MG, Brown AC, Shields B, Viganego F, Damrongwatanasuk R, Patel AA, et al. Developing a Comprehensive Cardio-Oncology Program at a Cancer Institute: The Moffitt Cancer Center Experience. Oncol Rev. 2017; $11(2) 18$ [cited 2020 Mar 26]Available from: https://www.ncbi.nlm.nih.gov/ pmc/articles/PMC5523022/.

35. Tan KS, Eguchi T, Adusumilli PS. Competing risks and cancer-specific mortality: why it matters. Oncotarget. 2017;9(7):7272-3.

36. Reck M, Rodríguez-Abreu D, Robinson AG, Hui R, Csőszi T, Fülöp A, et al. Pembrolizumab versus Chemotherapy for PD-L1-Positive Non-Small-Cell Lung Cancer. N Engl J Med. 2016;375(19):1823-33.

37. Peters S, Camidge DR, Shaw AT, Gadgeel S, Ahn JS, Kim D-W, et al. Alectinib versus Crizotinib in Untreated ALK-Positive Non-Small-Cell Lung Cancer. N Engl J Med. 2017;377(9):829-38.

38. Soria J-C, Ohe Y, Vansteenkiste J, Reungwetwattana T, Chewaskulyong B, Lee KH, et al. Osimertinib in Untreated EGFR-Mutated Advanced Non-SmallCell Lung Cancer. N Engl J Med. 2018;378(2):113-25.

39. Paz-Ares L, Luft A, Vicente D, Tafreshi A, Gümüş M, Mazières J, et al. Pembrolizumab plus Chemotherapy for Squamous Non-Small-Cell Lung Cancer. N Engl J Med. 2018;379(21):2040-51.

40. Gandhi L, Rodríguez-Abreu D, Gadgeel S, Esteban E, Felip E, De Angelis F, et al. Pembrolizumab plus chemotherapy in metastatic non-small-cell lung Cancer. N Engl J Med. 2018;378(22):2078-92.

41. Opdivo for Non-Small Cell Lung Cancer - Details [Internet]. CADTH.ca. 2015 [cited 2020 Mar 10]. Available from: https://www.cadth.ca/opdivo-non-smallcell-lung-cancer-details.

42. Keytruda for Non-Small Cell Lung Cancer (Second Line or Beyond) - Details [Internet]. CADTH.ca. 2016 [cited 2020 Mar 10]. Available from: https://www. cadth.ca/keytruda-non-small-cell-lung-cancer-second-line-or-beyond-details.

\section{Publisher's Note}

Springer Nature remains neutral with regard to jurisdictional claims in published maps and institutional affiliations.

Ready to submit your research? Choose BMC and benefit from:

- fast, convenient online submission

- thorough peer review by experienced researchers in your field

- rapid publication on acceptance

- support for research data, including large and complex data types

- gold Open Access which fosters wider collaboration and increased citations

- maximum visibility for your research: over $100 \mathrm{M}$ website views per year

At $\mathrm{BMC}$, research is always in progress.

Learn more biomedcentral.com/submissions 